University of Nebraska - Lincoln

DigitalCommons@University of Nebraska - Lincoln

Papers in Ornithology

Papers in the Biological Sciences

2005

Using molt limits to age Western Bluebirds

Daizaburo Shizuka

University of Nebraska-Lincoln, dshizuka2@unl.edu

Janis L. Dickinson

Hastings Natural History Reservation, Carmel, CA

Follow this and additional works at: https://digitalcommons.unl.edu/biosciornithology

Shizuka, Daizaburo and Dickinson, Janis L., "Using molt limits to age Western Bluebirds" (2005). Papers in Ornithology. 87.

https://digitalcommons.unl.edu/biosciornithology/87

This Article is brought to you for free and open access by the Papers in the Biological Sciences at DigitalCommons@University of Nebraska - Lincoln. It has been accepted for inclusion in Papers in Ornithology by an authorized administrator of DigitalCommons@University of Nebraska - Lincoln. 


\title{
Using molt limits to age Western Bluebirds
}

\author{
Daizaburo Shizuka ${ }^{1}$ and Janis L. Dickinson \\ Hastings Natural History Reservation, 38601 East Carmel Valley Road, Carmel Valley, California 93924 USA
}

Received 30 October 2003; accepted 20 September 2004

\begin{abstract}
Using data on the extent of prebasic molt in known-aged adult and first-winter Western Bluebirds (Sialia mexicana), we assessed the accuracy of the molt limit as a tool for ageing birds. Sixty-nine known-aged birds were examined over the winter 2002-2003 in upper Carmel Valley, California. We also examined 29 breeding males in spring 2004 to assess the accuracy of this method for ageing birds during the breeding season. All birds were aged correctly using molt limit as the defining characteristic. We found that all first-winter birds had replaced 2-8 greater secondary coverts, while adults had replaced all wing coverts. We observed no significant sexual variation in the extent of first prebasic molt. These results indicate that the extent of prebasic molt is a highly reliable means of ageing birds in this population.
\end{abstract}

\section{SINOPSIS. Utilización de limites en la muda para determinar la edad de Sialia mexicana}

Utilizando datos sobre la longitud del periodo de muda prebásica en adultos de edad concoida y la del primer invierno en Sialia mexicana, determinamos con exactitud los límites en el periodo de muda como herramienta para determinar la edad de las aves. Durante el invierno de 2002-2003, examinamos 69 individuos en la parte superior del Valle Carmel, California. Además examinamos 29 machos en etapa reproductiva durante la primavera del 2004 para determinar la exactitud del método para determinar la edad las aves durante la época de reproducción. La edad de todas las aves fue determinada correctamente utilizando los límites de muda como método. Encontramos que todas las aves de primer invierno han remplazado de 2-8 las cobijas de las secundarias, mientras que los adultos han remplazado todas las cobijas del ala. No se encontró diferencia significativa de variedad en los sexos en la primera muda prebásica. Estos resultados indican que la extensión del plumaje prebásico es una forma altamente confiable para determinar la edad en la problación estudiada.

Key words: ageing birds, Hastings Natural History Reserve, moult, passerine, plumage

The ability to distinguish age classes in birds is important when studying age-related differences in characters such as survivorship, habitat selection, reproductive success, foraging success, migratory behavior, dominance, plumage, and morphology (Mulvihill 1993). Accurate and practical methods of determining the age classes of birds thus are of great interest for field ornithologists.

Since Dwight (1900), differences in the molt of adults and birds in their first year of life have been described for many species of passerines. The first prebasic molt is often only partial, resulting in a molt limit, or a point of discontinuity in the generation of feathers in a certain tract (Jenni and Winkler 1994; Pyle 1997a; Deviche 2000). When the molt limit can be detected by color and wear of feathers, these distinct patterns of molt provide a means to dis-

\footnotetext{
${ }^{1}$ Corresponding author. Current address: Department of Ecology and Evolutionary Biology, A308 Earth and Marine Sciences Building, University of California, Santa Cruz, California 95064 USA. Email: Shizuka@biology.ucsc.edu
}

tinguish yearlings and younger birds from older adults, for which molt is usually complete and no molt limits exist (Mulvihill 1993; Jenni and Winkler 1994; Pyle 1997a). Although the use of this technique has been discussed in detail for European passerines (Jenni and Winkler 1994), there is still much work to be done for North American species (Pyle 1997b).

For the Western Bluebird (Sialia mexicana), published information on first prebasic molts was obtained from museum specimens collected throughout its range (Pyle 1997a). Data collected from specimens or unmarked live birds in the field are often incomplete because the age of each bird must be inferred from other features such as skull pneumaticization or a combination of plumage characteristics (Mulvihill and Winstead 1997; Deviche 2000). The use of the tenth primary for determining age has been discussed for Eastern Bluebirds (Sialia sialis, Pitts 1985), and this was found to be useful in Western Bluebirds, with 93\% accuracy based on 14 known-aged males and 90\% accuracy based on 10 known-aged females band- 
ed as nestlings (J. L. Dickinson, unpubl. data). However, this method can be more difficult than molt limits because it requires an evaluation of shape and color without a means for direct comparison between two generations of feathers.

At Hastings Natural History Reservation, located in upper Carmel Valley, California, Western Bluebirds have been monitored since 1983. During this period, all Western Bluebirds hatched in nest boxes were banded in the nest before fledging. In this study, we show that the discontinuity in color and wear of feathers at the molt limit provides a reliable and practical ageing technique for Western Bluebirds in this population based on data from known-aged birds banded as nestlings. We also describe the individual and sexual variation in the first prebasic molt of the upper alar region of these birds.

\section{METHODS}

We recorded the extent of molt in the upper alar tract of 69 known-aged Western Bluebirds captured at Hastings Natural History Reservation and nearby Rana Creek Ranch during October 2002-February 2003. In addition, we caught 20 previously unbanded Western Bluebirds and examined their extent of molt during the same period. We described the molt limit prior to confirming the age based on recapture records so that all assignments were "blind" with respect to the actual age of the bird. Sampled birds were classified as "first-winter" if they were within one calendar year of hatching during winter capture, and as "adults" if captured after their first season as a potential breeder. Digital photographs were taken as a permanent record, and these are available upon request from the corresponding author.

To determine whether the molt patterns seen in winter persisted into the breeding season, we examined the molt limit of 29 known-aged males from 27 April to 30 June 2004. These birds were categorized as "first-breeder" if this was their first breeding season, and "adults" if older, using the same methods.

In order to make sure we were not examining birds before the completion of their molt, we recorded the level of body molt on 55 of the 89 individuals used in the sample. No birds were observed to have more than a few molting

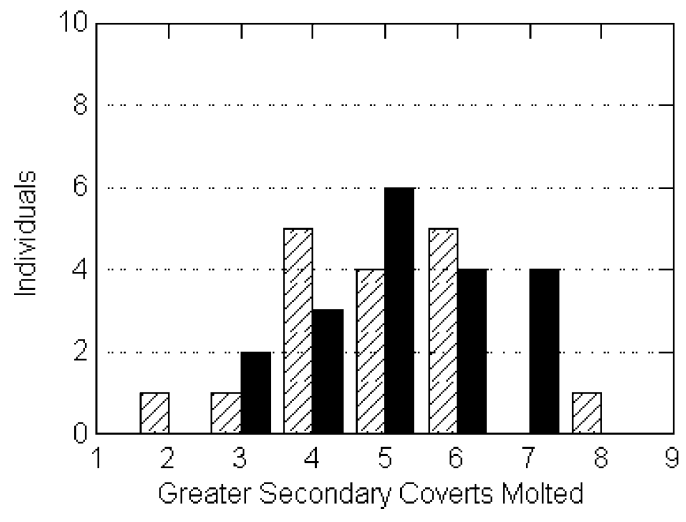

Fig. 1. Extent of molt recorded for female and male Western Bluebirds with partial molts during the winter of 2002-2003. Black bars are for males and striped bars for females.

body feathers throughout the sampling season, and these likely resulted from adventitious feather replacement.

Means ( \pm SE) are presented. A Mann-Whitney $U$-test was performed for the statistical analysis of sexual variation.

\section{RESULTS}

The molt limits of male Western Bluebirds were quite easy to discern, with the new generation of feathers appearing bright blue with fresh edges, while the retained juvenile feathers were more grayish with abraded edges. The color difference in generation of feathers in females was less distinct due to the duller adult feathers, but with proper light and familiarity with the subject, all researchers involved could determine molt limits reliably.

All known-aged first-winter birds examined in 2002-2003 $(N=24)$ and all first-breeder males examined in spring $2004(N=8)$ were found to have a partial molt resulting in a detectable molt limit. In contrast, no known-aged adult birds in the winter 2002-2003 $(N=45)$ or spring $2004(N=21)$ were found to have a molt limit. Molt limits always occurred in the greater secondary coverts.

In birds exhibiting partial molt during winter 2002-2003 $(N=36)$, all lesser and median coverts as well as two to eight $(5.08 \pm 0.22)$ inner greater secondary coverts were replaced (Fig. 1). The feathers molted were always the proximal group of the greater secondary co- 
verts. The distal greater secondary coverts, carpal covert, greater primary coverts and the flight feathers were always retained. Thirteen of 36 birds (36\%) exhibiting partial molt showed asymmetry in the extent of molt on the left and right wing. Of these, three birds $(8 \%)$ had a difference of two feathers between the wings, and 10 birds $(28 \%)$ had a difference of one feather. We found no statistically significant difference in the number of feathers molted in the greater secondary coverts between males $(N=$ $19)$ and females $(N=17)$ in this population $(U=188.5, P=0.372)$, although the average for females was slightly smaller $(4.88 \pm 0.34)$ than for males $(5.26 \pm 0.29)$ (Fig. 1).

\section{DISCUSSION}

The molt limit proved to be a practical and accurate method for distinguishing first-winter and first-breeder birds from older adult Western Bluebirds. The presence or absence of molt limit correctly aged $100 \%$ of 69 male and female known-aged Western Bluebirds captured in the winter and 29 males captured during the breeding season. The contrast between juvenal and mature wing covert feathers was clearly discernible, especially in males. For females, molt limits were identified by contrast in color and wear of feathers, with the fresh, replaced feathers having a blue tint and fresh edges, while the old retained feathers were almost completely grayish brown with worn edges.

Determining the age of birds by skull ossification can be technically difficult for beginners, especially for species such as Western Bluebirds that have relatively thick cranial skin (Pyle 1997b). In addition, while the skull ossification method is only informative until fall/ winter for Western Bluebirds, the molt limit is a useful tool from late summer/fall of the first year until the end of the breeding season of the second year (Pyle 1997a). General plumage characteristics such as amount of blue color, flight feather wear, and rectrix shape and wear may aid in the determination of age in birds, but individual variation and behavioral effects on the rate of feather wear can render these characteristics unreliable.

A previous study using museum specimens of Western Bluebirds $(N=30)$ showed a range of 2-10 greater coverts replaced, with $33 \%$ of birds having replaced all 10 greater coverts and
$17 \%$ having replaced $1-4$ feathers of the tertials and secondaries (Pyle 1997a). Our study shows a different result, with the range of greater coverts replaced at $2-8$, and no tertials or secondaries replaced. This difference may well be attributed to geographic variation, as the specimens sampled by Pyle (1997a) were collected throughout the range of the Western Bluebird, whereas our birds were collected from a single valley in the coast range of central California. Geographic variation in extent of molt has been documented in several species of passerines (e.g., jays, Pitelka 1945; juncos, Mulvihill and Winstead 1997).

We observed no significant sexual variation in the extent of molt. Chandler and Mulvihill (1990) hypothesized that the timing of migration may affect the timing and extent of the first prebasic molt in Dark-eyed Juncos (Junco hyemalis). Mulvihill and Winstead (1997) found sexual variation in two different populations of migrating Dark-eyed Juncos, with the earlier-departing females having less extensive replacement of wing feathers. Since our sampled individuals were year-round residents of upper Carmel Valley, we might not expect sexual differences in the extent of molt. On the other hand, there is sexual variation in distance and timing of dispersal in this population, with females having the tendency to leave their natal sites and move to new winter flocks by late summer (Kraiijeveld and Dickinson 2001). Thus, our results suggest that sexual differences in natal dispersal do not affect molt extent.

\section{ACKNOWLEDGMENTS}

We thank Leah Bernsten, Amber Budden, Katherine Eldridge, Katherine Greenwald, Andrew McGowan, Kathleen Rudolph, and Erica Westerman for help with data collection, and our assistants from prior years for their banding efforts. We also thank Rana Creek Ranch for allowing us to access their land for this project. This research was supported by NSF (IBN-009702).

\section{LITERATURE CITED}

Chandler, C. R., And R. S. Mulvihill. 1990. Wingshape variation and differential timing of migration in Dark-eyed Juncos. Condor 92: 54-61.

Deviche, P. 2000. Timing, pattern, and extent of first prebasic molt of White-winged Crossbills in Alaska. Journal of Field Ornithology 78: 217-226.

Dwight, J. 1900. The sequence of plumages and moults of the passerine birds of New York. Annals of the New York Academy of Science 13: 73-360.

JENNI, L., AND R. WinkLER. 1994. Moult and ageing of 
European passerines. Academic Press, New York, NY.

Kraijeveld, K., And J. L. Dickinson. 2001. Familybased winter territoriality in Western Bluebirds, Sialia mexicana: the structure and dynamics of winter groups. Animal Behaviour 61: 109-117.

Mulvihill, R. S. 1993. Using wing molt to age passerines. North American Bird Bander 18: 1-10. -, AND R. L. Winstead. 1997. Variation in the extent of the first prebasic wing molt of Dark-eyed Juncos. Journal of Field Ornithology 68: 183-199.
Pitelka, F. A. 1945. Pterylography, molt and age determination of American jays of the genus Aphelocoma. Condor 47: 229-226.

PITTS, D. T. 1985. Identification of second-year and after-second-year Eastern Bluebirds. Journal of Field Ornithology 56: 422-424.

Pyle, P. 1997a. Molt limits in North American passerines. North American Bird Bander 22: 49-89.

1997b. Identification guide to North American Birds. Part I. Columbidae to Ploceidae. Slate Creek Press, Bolinas, CA. 